\title{
Evaluation and treatment of tinnitus
}

Keywords: tinnitus, nosologic entity, humming sensation, primary tinnitus, cognitive behavior therapy

Abbreviations: PT, primary tinnitus; ST, secondary tinnitus; TSOAE, transient stimulation of otoacoustic emissions; VAS, visual analog scale; THI, tinnitus handicap inventory; CBT, cognitive behavior therapy; TAT, tinnitus activities treatment

\section{Introduction}

Tinnitus is characterized by being a symptom of an underlying nosologic entity. It is described as the sensation of noise in the absence of a corresponding external sound stimulus. Many individuals don't feel disturbed by this symptom. ${ }^{1-6}$ On the other hand, however, the humming sensation can have a significantly negative impact on one's quality of life, besides being related to other problems that affect cognitive functions.

\section{Incidence}

The prevalence of tinnitus in the general population was estimated by various studies to vary from $5,1 \%$ to $42,7 \%$ with a greater incidence in the male population, tending to increase with age. In the paediatric population the prevalence ranges from $6 \%$ to $41,9 \%$ whilst for children with hearing loss it affects $23,5 \%$ to $62,5 \%$. It should be noted, however, that it's uncommon for children to suffer from tinnitus alone..$^{7-10}$

\section{Classification}

i. Primary Tinnitus (PT): idiopathy associated or not to a sensorineural hearing loss.

ii. Secondary Tinnitus (ST): associated to an underlying known cause (with the exception of sensorineural hearing loss), or a known organic condition. It's a symptom of a disorder in the hearing system.

\section{Clinical evaluation of tinnitus}

a. Anamnesis.

b. Desciption of the humming sensation.

c. Research on associated health factors.

d. Basic audiological evaluation and measurement of acoustic immittance.

e. Transient stimulation of otoacoustic emissions (TSOAE) and distortion-product otoacoustic emissions (DPOAE).

f. Acuphenometry.

g. Quality-of-life questionnaires, visual analog scale (VAS) or Tinnitus Handicap Inventory (THI).

\section{Treatment for tinnitus}

Some authors divide the treatment in two categories: pharmacological treatment and electric stimulation, the other
Volume 6 Issue 6 - 2017

Scheila Farias de Paiva, Isis Paloma Silva Aragão, Anne Thamires Santos Sampaio, Marília Evellyn Hilário dos Santos, Fabio Rafael Teixeira de Santana

Study Group of Audiology and Otoneurology the Sergipe Federal University, Brazil

Correspondence: Scheila Farias de Paiva Study Group of Audiology and Otoneurology the Sergipe Federal University, Brazil,Email spaivafono@yahoo.com.br

Received: October 30, 2016 | Published: April 19, 2017

consisting of pharmacotherapy, cognitive behavior therapy, sound therapy (retraining therapy and masking therapy), massage and stretching, acupuncture, hearing instruments amongst others.

Therapies in which a phonoaudiologist is effectively involved:

A. Tinnutus Retraining Therapy

B. Hipersensibility (Tinnitus Retraining)

C. Tinnitus Masking Therapy (Tinnitus Activities Treatment - TAT)

D. Cognitive behavior therapy (CBT)

E. Neck and masticatory muscle massages and stretching

\section{Conclusion}

In view of what has been exposed here, there is a need of an extensive and thorough clinical evaluation of patients who suffer from tinnitus, with the need of assessments and specialized examinations whenever necessary in order to detect its origin and, hence, the best treatment for the patient. ${ }^{11-18}$ In its multi professional team, the Fonoaudiologist is highlighted, since this is who is responsible for the evaluation, diagnostic and development of intervention strategies for the treatment of tinnitus.

\section{Acknowledgments}

None.

\section{Conflicts of interest}

Author declares there are no conflicts of interest.

\section{Funding}

None.

\section{References}

1. McCormack A, Edmondson-Jones M, Somerset S, et al. A systematic Review of the reporting of tinnitus prevalence and severity. Hear Res. 2016;337:70-79. 
2. Tunkel DE, Bauer CA, Sun GH, et al. Clinical Practice Guideline: Tinnitus. Otolaryngol Head Neck Surg. 2014;151(2 Suppl):S1-S40.

3. Silvio CN, João FMJ, Regina HGMSSC. Tratado de Otorrinolaringologia. In: Roca (Ed.), 2nd edn. São Paulo. 2015. p.465-477.

4. Baguley D, McFerran D, Hall D, et al. Tinnitus. Lancet. 2013;382(9904):1600-1607.

5. Tegg-Quinn S, Bennett RJ, Eikelboom RH, et al. The impact of tinnitus upon cognition in adults: A systematic review. Int $J$ Audiol. 2016;55(10):533-540

6. Rosing SN, Schmidt JH, Wedderkopp N, et al. Prevalence of tinnitus And hyperacusis in children and adolescents: a systematic review. $B M J$ Open. 2016;6(6):010596.

7. Baguley $\mathrm{D}, \mathrm{McF}$ rrran $\mathrm{D}$, Nodar RH, et al. Tinnitus in childhood. Int $J$ Pediatr Otorhinolaryngol. 1999;49(2):99-105.

8. Schmidt LP, Teixeira VN, Dall'Igna C, et al. Adaptação para língua portuguesa do questionário Tinnitus Handicap Inventory: validade e reprodutibilidade. Braz J Otorhinolaryngol. 2006;72(6):808-810

9. Ventura DP, Guedes APS. Avaliação auditiva: testes básicos. In: Mor $\mathrm{R}$ (Ed) Conhecimentos essenciais para entender uma avaliação auditiva básica. São José dos Campos: Pulso. 2003. p.20.

10. Rossi AG.Imitanciometria. In: Frota $\mathrm{S}$ (Ed) Fundamentos emfonoaudiologia: audiologia. Guanabara: Rio de Janeiro. 2003. p.7786.
11. Hood L, Berlin CI. Clinical pplications of otoacoustic emissions In: Erlin CI, et al. (Eds.), Hair cell micromechanics and otoacoustic emissions. Thomson Learning, New York, USA. 2002. p.121-138.

12. Urnau D, Tochetto TM. Características do zumbido e da Hiperacusia em IndivíduosNormo-ouvintes. Artigo Original Otorrinolaringol. 2011;15(4): 468-474.

13. Seabra R. Acufenos: via final comum e estratégia terapêutica. ClinInves Otorri. 2007. p.232-236

14. Esteves CC. Audição, zumbido e qualidade de vida: um estudo piloto. Rev CEFAC. 2012;14(5):836-843.

15. Lustig LR, Schindler JS. Ear Nose \& Throat Disorders. In: Papadakis, et al. (Eds.), Current Medical Diagnosis \& Treatment. New York, NY, USA. 2016.

16. Imlau D.Análise do Benefício do Tratamento de Zumbido com Geradores de Ruído: estudo de Caso. 2015. p.29.

17. Hall DA. Systematic review of outcome domains and instruments used In clinical trials of tinnitus treatments in adults. Trials. 2016;17:270.

18. Rosa MRD. Zumbido e ansiedade: uma revisão da literatura. Rev. CEFAC. 2012;14(4):742-754. 